PEKPEAUIЙHA ГEOTPADIS

УДК 911.3

\title{
К.Д. Діденко
}

РОЛЬ ІСТОРИЧНИХ МІСТ УКРАЇНИ В РОЗВИТКУ ВНУТРІШНЬОГО ТУРИЗМУ

\author{
К.Д. Диденко \\ РОЛЬ ИСТОРИЧЕСКИХ ГОРОДОВ УКРАИНЫ В РАЗВИТИИ ВНУТРЕННЕГО ТУРИЗМА \\ Киевский Университет туризма, экономики и права
}

В статье рассматривается роль и место исторических населенныхпунктов Украины как ресурсадля развития внутреннего туризма. Проанализированы перспективы использования их потенциала в туристической сфере. Рассматривается вопрос специфики застройки и пространственной организации исторических городов при формировании их как центров туризма. Охарактеризована система мероприятий, которые необходимо внедрять для дальнейшего развития туризма в исторических городах.

Ключевые слова: исторические населенные пункты; культурно-историческое наследие; внутренний туризм; туристический потенциал.

\section{K.D. Didenko \\ THE ROLE OF UKRAINIAN HISTORIC CITIES IN INTERNAL TOURISM DEVELOPING}

Kyiv University of Tourism, Economics and Law

The article discusses the role and place of Ukraine's historic settlements as a resource of domestic tourism development. The prospects of their potential use in the tourism sector have been analyzed. The specifics of development construction and spatial organization in historic towns when forming them as the tourist attraction centers has been looked into. The system of necessary measures which should be implemented for further tourism development in historic cities have been characterized.

Keywords: historic towns and settlements; cultural and historical heritage; domestic tourism; tourism potential.

\section{Вступ. Постановка проблеми}

Нове розуміння культури в суспільстві й усвідомлення необхідності збереження культурної спадщини у світі розширюють перспективи розвитку культурно-пізнавального туризму, подальше використання історико-культурного потенціалу стародавніх та історичних міст як ресурсу регіонального розвитку, а також впливу на соціальну й культурну сферу, екологію, зовнішньоекономічну діяльність і міжнародні відносини.

Незважаючи на всі труднощі, наш час є періодом розвитку нових тенденцій у культурному житті, відроджуються раніше забуті імена, пам'ятки й події, по-новому оцінюється історична спадщина. I тому для більшості українських регіонів орієнтація на культурно-пізнавальний туризм, на основі використання потенціалу історичних міст, стає однією 3 реальних можливостей економічного, соціального й культурного піднесення.

\section{Аналіз останніх досліджень і публікацій}

Серед наукових публікацій останніх років стосовно цієї тематики можна назвати теоретичні праці російських вчених Ю.Л. Мазурова (дослідження питань географії природної та культурної спадщини), О.П. Мамонова (дослідження соціальнокультурних особливостей малих історичних міст Росіі). 3 українських дослідників слід виділити монографію К.А. Поливач [3]. Креативним стра- тегіям розвитку міст, зокрема 3 акцентом на розвиток культури, мистецтва, збереження історичної спадщини (у т.ч. і стратегії ЮНЕСКО) присвячено публікацію [8]. Однак грунтовнішого підходу потребують питання використання наявного потенціалу історичних міст для туризму, 3 одного боку, та збереження історичної самобутності й цінності таких населених пунктів - 3 іншого.

М е т а цієї статті - дослідження ролі історичних міст України як ресурсу розвитку внутрішнього туризму.

\section{Виклад основного матеріалу}

Значна частина населення України проживає у малих містах та селищах. Нині більшість цих населених пунктів $\epsilon$ депресивними, характеризуються низьким рівнем соціально-економічного розвитку, зайнятості, високою трудовою міграцією населення. Враховуючи те, що більша частина малих міст $\epsilon$ монофункціональними, але при цьому мають значний туристично-рекреаційний, культурно-історичний та природний потенціал, активізацію розвитку сфери туризму та рекреації можна розглядати інструментом сприяння розвитку малих міст України, підвищення рівня зайнятості, зменшення обсягів молодіжної трудової міграції та посилення підприємницької ініціативи.

Перспективними у цьому контексті можуть бути регіони зі знаною часткою історичних міст 
3 давніми культурними традиціями i, як правило, збереженими історичними пам'ятками, які формують “обличчя" певного населеного пункту, що є ключовим для сприйняття туристів, а також з відповідною ініціативною діяльністю громадських організацій (зокрема створені Асоціація малих історичних міст Західної України, Асоціація розвитку курортних міст Українського Причорномор'я "Таврія", функціонує Секція малих міст та Секція історичних міст у межах діяльності Всеукраїнської недержавної організації “Асоціація міст України").

Що ж таке історичне населене місце? Це місто, селище або село, яке зберегло повністю або частково свій історичний ареал з об'єктами культурної спадщини і пов'язані з ними розпланування та форму забудови, типові для певних культур або періодів розвитку.

В Україні до Списку історичних населених місць внесено 400 міст і селищ міського типу.

Проведений аналіз Списку свідчить про значну нерівноцінність та диференціацію різних регіонів України за кількістю міст і селищ міського типу, виявлених і внесених до Списку історичних населених місць України, - від чотирьох (Миколаївська область) до 55 (Львівська область). Значну кількість історичних населених місць зафіксовано також у Тернопільській, Івано-Франківській областях та АР Крим. У Дніпропетровській, Запорізькій, Кіровоградській, Херсонській, Донецькій та Київській областях менше ніж по 10 історичних населених місць, включених до Списку.

Згідно 3 «Порядком визнання населеного місця історичним», затвердженим Постановою Кабінету Міністрів України 3 липня 2006 року за № 909, місто, селище та село можна визнати історичним i внести до Списку, якщо воно відповідає щонайменше двом 3 таких критеріїв:

1) наявність історичних, архітектурних, ландшафтних та садово-паркових об'єктів культурної спадщини, які мають містоформуюче значення;

2) розпланування відповідно до минулих історичних епох (до початку ХХ століття);

3) збереження основних композиційних центрів і композиційних осей населених місць;

4) наявність рядової історичної забудови.

За сучасним визначенням, історичні міста пов'язані з охороною історико-культурної спадщини, оскільки вони уособлюють цінності, притаманні традиційним міським цивілізаціям, i зберегли впродовж віків неповторне обличчя, традиційну планувальну структуру, відповідне культурне, історичне й архітектурне середовище.

Поняття «історичне місто» вперше 3'явилося в ухваленій 1987 p. Міжнародною радою 3 питань пам'яток i визначних місць (IKOMOS) Вашингтонській Міжнародній хартії про охорону історичних міст. Вона доповнює Венеціанську Міжнародну хартію 3 охорони й реставрації нерухомих пам'яток і визначних місць, прийняту 1964 року.

Співробітники Київського науково-дослідного інституту теорії та історії архітектури і містобудування розробили категорії переліку населених місць із цінною історико-культурною спадщиною. У ньому виділено чотири категорії цінності населеного пункту, де взято до уваги ступінь збереженості та комплексності архітектурно-містобудівної й історико-культурної спадщини; історична значущість (роль) населеного пункту; категорія охорони (тоді загальнодержавного, тепер національного чи місцевого значення) розміщених на його території пам'яток, їх унікальність; наявність цінних історичних і природних ландшафтів [6].

До п е рш о $і$ к а т г о р ї̈ виключно цінних увійшли ті населені місця, де збереглися первинні містобудівні композиції, схеми просторової організації; історичне планування, монументальні споруди як просторові й функціональні домінанти, цінна житлова забудова. Було виявлено 50 населених місць, які мають райони, що відповідають статусу заповідників і заповідних місць, та запропоновано 39 міст першої категорії. Серед них особливо виділено шість: Київ, Львів, Одеса, Луцьк, Харків, Чернігів.

Друга категорія - населені місця, де збереглись основні особливості первинної містобудівної композиції та просторової організації території, характер історичного планування, частина раніш існуючих монументальних споруд громадського призначення, окремі комплекси історичної житлової забудови. Віднесений до цієї категорії 91 населений пункт потребує встановлення в межах історичного центру суворого режиму регулювання, визначення заповідних територій або охоронних зон.

Т ретя категорія - 323 населені місця 3 частково збереженою первинною містобудівною композицією 3 фрагментарним історичним плануванням і забудовою, поодинокими історичними монументальними спорудами.

Ч е т в ер та ка т егорія - 930 населених пунктів 3 поодинокими пам'ятками історії та культури, окремими фрагментами історичного середовища [2].

Найбільше поселень 3 цінною спадщиною у Львівській (112), Київській (97), Тернопільській і Закарпатській областях (по 88), найменше - в Херсонській (28). За уточненими даними, нині в Україні налічується 1399 міст і селищ та понад 8 тисяч сіл із цінною історико-архітектурною спадщиною. Ïї фонд у цих населених пунктах, за підрахунками фахівців, перевищує 70 тисяч об'єктів [3].

Процеси розвитку, реконструкції, забудови, інвестиційної діяльності в історичних ареалах по- 
требують особливо зваженого підходу, вони мають грунтуватися на засадах збереження й оптимального використання об'єктів нерухомої культурної спадщини, охорони історико-архітектурного середовища. Історичні населені місця є основними елементами історико-культурного каркасу.

Загрозою для самобутності історичних міст завжди було втручання нової забудови в історичне середовище. У наш час існує небезпека того, що зростаюча універсальність методів будівництва й архітектурних форм здатна призвести до створення одноманітного оточення в усьому світі. Збереження історичного або традиційного середовища в такому разі може стати видатним внеском у справу охорони культурних і соціальних цінностей країни й таким чином одночасно сприяти збагаченню світової культурної спадщини в галузі архітектурного та містобудівного мистецтва. Це, в свою чергу, сприятиме розвитку культурно-пізнавального туризму на основі використання потенціалу стародавніх міст і містечок.

Кожне з 400 історичних міст України, перелік яких затверджено постановою Кабінету Міністрів [5], - окрема сторінка у літопису держави. Безліч історичних подій, що суттєво вплинули на хід розвитку цивілізації, відбувалися протягом століть на цій землі. Тому наша історія та культурна спадщина цікаві не тільки в Україні, а й за ії межами. Проте слід зазначити, що цей величезний потенціал туризму є майже не задіяним сьогодні.

У наш час зростає інтерес до міського туризму, викликають зацікавленість автентичність, місцева культура та історія, а отже стають популярними подорожі, які поєднують відпочинок і розваги з вивченням культурних та історичних принад.

Для розвитку малих міст 3 цінним історикокультурним потенціалом туризм може і має стати одним із пріоритетних напрямків. Критерієм сприятливості для розвитку туризму є наявність в них об'єктів, які відповідають таким вимогам:

1) унікальність, незвичайність, відсутність аналогів в інших регіонах;

2) широка популярність;

3) пізнавальна цінність, зв'язок 3 важливими історичними подіями, видатними особистостями світової історії;

4) висока художня цінність самого об'єкта i його оточення;

5) збереження й підготовленість до показу;

6) зручність і доступність розташування.

Надання туристських функцій малим історичним містам потребує внесення суттєвих змін до їх містобудівної організації.

Специфіку планування і забудови, ландшафтних умов, композиційно-просторової організації малих міст слід обов'язково враховувати при формуванні їх як центрів туризму [4].
Розвиток туристської інфраструктури. Ефективне функціонування туристських центрів неможливе без розвиненої інфраструктури. Смність цих об'єктів, особливо привабливих для приватних інвестицій, залежить від зростання туристичних потоків і збільшується поетапно. Першочерговою умовою має бути їх зручна доступність - як між собою, так і по відношенню до основних туристично-екскурсійних маршрутів.

Просторове розмежування функцій обслуговування туристів і проживання місцевого населення. Збільшення туристичних потоків може викликати необхідність використання внутрішньоквартальних територій для розвитку інфраструктури. Наприклад, на дворових просторах, що стикаються 3 туристськими трасами, можливі влаштування літніх кафе, озеленених місць відпочинку для туристів, організація наскрізних пішохідних проходів на сусідні вулиці, створення автостоянок і тому подібне.

Слід зазначити, що житло в зонах історичної забудови більшою чи меншою мірою збережеться і в майбутньому. При цьому з розвитком туризму неминуче виникнення протиріч між інтересами i потребами туристів і місцевих жителів. Тому важливим питанням $є$ просторове розмежування функцій обслуговування туристів і проживання місцевого населення, створення повноцінного життєвого середовища для місцевого населення, яке проживатиме в межах формованих культурнотуристських зон.

Сучасне використання історичної забудови. Значна частина історичної забудови малих міст України потребує реконструкції та модернізації з обов'язковим збереженням особливостей композиційно-просторових рішень.

Стосовно нової забудови, яка доповнює збережену, при iï формуванні обов'язково слід враховувати історичні традиції, що дозволить зберегти своєрідність вигляду поселень.

Розвиток туризму змушує по-іншому поглянути на відтворення унікальних, нині втрачених архітектурних споруд. Для відновлення особливостей історичного середовища важливе значення мають збережені фотографії, поштові листівки, малюнки художників тощо.

Організація ландшафтно-рекреаційних територій. Як місця відпочинку туристів можуть використовуватися історичні чи сучасні парки, інші природні ландшафти зі сприятливими умовами природними і штучними водоймами, лісопарками, озелененими просторами, зокрема облаштованими озелененими набережними, бульварами, скверами тощо. Поряд із використанням характерних особливостей місцевості важливо й відновлення істо- 
ричних ландшафтів, збереження головних їхніх елементів, що мають культурне, історичне, художнє значення.

Організація транспортних і пішохідних зв'язків. Збільшення людських і транспортних потоків 3 розвитком туризму в малих історичних містах потребує розвитку вулично-дорожньої мережі та вдосконалення транспортних зв'язків.

А це передбачає організацію зручних під’їздів, розрахованих на проїзд великогабаритних туристських автобусів до основних об'єктів туристського показу, готелів, найкоротшого сполучення між ними і залізничними та автобусними вокзалами; створення транспортних обходів зон концентрації історико-культурних цінностей та об' єктів обслуговування туристів, максимально можливого поділу транспортних і пішохідних шляхів сполучення; розміщення автостоянок необхідної ємності поблизу місць масових відвідувань. Доцільне створення пішохідних безтранспортних зон у місцях концентрації історико-культурних цінностей та об'єктів обслуговування туристів

Формування культурно-туристських $30 н$. Формування таких зон має забезпечувати охорону i підтримку в належному стані історико-культурних та природних цінностей, раціональне використання їх як об'єктів туризму, розвиток сервісної мережі. А це, в свою чергу, активізуватиме соціальноекономічні процеси в поселеннях, створення нових робочих місць, підвищення рівня доходів і поліпшення умов життєдіяльності місцевого населення.

3 точки зору абсолютної величини туристського потенціалу малі міста поступаються великим містам, а щільність об’єктів у них вища. Проте слід враховувати, що культурно-історичний потенціал малих міст - це не тільки конкретна кількість пам'яток історії та культури. У них збереглася до наших днів унікальна, самобутня культурно-історична спадщина. Ця спадщина дуже індивідуальна, що значно підвищує привабливість малих міст для туристсько-екскурсійного використання.

Важливим є й те, що культурна спадщина малих міст України, розташованої на стику східної й західної культур європейської цивілізації, має унікальні індивідуальні риси, увібравши в себе елементи цих обох культур. Це додає неповторності архітектурним ансамблям і окремим об'єктам, які не мають аналогів у світі.

Культурна спадщина малих міст України визна- чає туристське обличчя кожного 3 них.

Як комплексні територіальні об'єкти культурної і природної спадщини, малі міста України досить мальовничі й органічно вписуються в природне оточення, оскільки ця історична традиція українського містоутворення в малих містах збереглася більшою мірою, ніж у великих. Загалом слід зазначити, що малі міста України краще, ніж середні й великі, зберегли свою історичну та етнографічну своєрідність, в них відчутніший поступ історії, вони привабливіше відображають специфіку навколишньої місцевості, ближчі до природи, тісно пов'язані з сільським оточенням.

Саме ці якості роблять їх дуже придатними i перспективними для всебічного туристського освоєння. Будучи комплексними туристськими об'єктами, концентруючи пізнавальні та оздоровчо-туристські ресурси, вони можуть стати основою формування мережі унікальних культурно-історичних i природних територій як нової туристської мережі. Комплекність туристсько-рекреаційного потенціалу малих міст України дозволяє розробити високоефективний туристський продукт 3 використанням ресурсів самих міст та навколишніх територій.

\section{Висновки}

На основі вищевикладеного, можна зробити висновок, що для подальшого розвитку туризму в історичних містах України важливим є впровадження таких заходів:

1) створення готельної, транспортної та сервісної інфраструктури історичних міст;

2) формування характерних туристичних продуктів;

3) розвиток місцевих інститутів підтримки туризму;

4) пошук і залучення зовнішніх та внутрішніх ресурсів;

5) синхронізація зусиль стратегічних партнерів - держава, місцеве самоврядування, бізнес.

Безсумнівно, на часі порушити питання про надання особливого статусу історичним містам, однією з основних функцій яких має бути збереження історико-культурної спадщини - найважливішої частини національного багатства держави. Цей статус повинен бути відображений у відповідних нормативно-правових актах. Ці питання мають стати невід'ємною складовою регіонального і місцевого розвитку.

\section{Jimepamypa}

1. Веденин Ю.А. Основы географического подхода к изучению и сохранению культурного наследия // Наследие и современность. Информационный сборник. - Вып. 12. - Москва : Институт наследия, 2004 - С. 5-10.

2. Горбик В. О., Кот С. І. До питання про висвітлення історичних міст і сіл у «Зводі пам'яток історії та культури» // Дослідження історії малих та середніх міст України в контексті дальшого розвитку історичного краєзнавства. - Чернігів, 1990. - С. 53-62.

3. Поливач К.A. Культурна спадщина та її вплив на розвиток регіонів України / Наук.ред. Л.Г. Руденко. - Київ: Інститут географії НАН України, 2012. - 208 с. 
4. Савостіна Л.С. Порядок обліку нерухомих об'єктів культурної спадщини. Реалії таперспективи//ПраціНДІпам'яткоохоронних досліджень. - Вип. 7. - Київ: Фенікс, 2012. - С. 322-335.

5. Список історичних населених місць України (міста і селища міського типу) [Електронний ресурс]. - Режим доступу: - http:// www.heritage.com.ua/

6. Специфіка висвітлення пам'яток архітектури та містобудування історичних міст у «Зводі пам'яток історії та культури України» [Електронний ресурс]. - Режим доступу: http://www.viche.info/journal/NAUKOVA_BIBLIOTEKA

7. Сущинская М.Д. Культурный туризм: учеб. пособие. - СПб.:Изд-во СПбГУЭФ, 2010. - 128 с.

8. Шевцзова А.О. Креативні стратегії розвитку міст: сутність поняття та підходи до його розуміння // Український географічний журнал. - 2014. - № 2 - С. 39-43.

\title{
References
}

1. Vedenin Y.A. (2004). Fundamentals of geographical approach to cultural heritage study and preservation. Heritage and our time. Informative collection, Vol. 12. Moscow: Institute of Heritage, 5-10.

2. Gorbik V.O., Kot S.I. (1990). On the coverage of historic towns and villages in the «Code of history and culture landmarks". Research of Ukraine small and medium-sized cities history in the context of further development of the historical regional studies. Chernihiv, 53-62.

3. Polivach K.A. (2012). Cultural heritage and its impact on Ukraine regional development; scientific editor L.G. Rudenko. Kyiv: Institute of Geography of Ukraine NAS.

4. Savostina L.Ye. (2012). Procedure for registration of cultural heritage real estate objects. Realities and prospects. Works of the monuments protection Research Institute. Vol. 7. Kyiv: Phoenix, 322-335.

5. List of historical settlements in Ukraine (cities and towns): http://www.heritage.com.ua/

6. Specifics of architectural landmarks coverage of and urban development of historic cities in the «Code of Monuments of History and Culture in Ukraine»: http://www.viche.info/journal/NAUKOVA BIBLIOTEKA

7. Suschynskaya M.D. (2010). Cultural tourism: Textbook. St. Petersburg.: Ed. SPbGUEF.

8. Shevtsova A.O. (2014). Creative strategies for urban development: the concept essence and approaches to its understanding. Ukrainian Geographical Journal, 2, 39-43.

Київський університет туризму, економіки і права

Стаття надійшла до редакції 29.07.2014

УДК 615.838:504.062.2].004.14(477)

\section{С.В. Леонова \\ КРИТЕРІЇ КОМПЛЕКСНОГО ОЦІНЮВАННЯ ПРИРОДНИХ ТЕРИТОРІЙ КУРОРТІВ УКРАЇНИ ДЛЯ ВИЗНАЧЕННЯ ЇХ СТАТУСУ}

\author{
С.В. Леонова \\ КРИТЕРИИ КОМПЛЕКСНОГО ОЦЕНИВАНИЯ ПРИРОДНЫХ ТЕРРИТОРИЙ КУРОРТОВ УКРАИНЫ ДЛЯ ОПРЕДЕЛЕНИЯ ИХ \\ СТАТУСА
}

Украинский научно-исследовательский институт реабилитации и курортологии МОз Украины, Одесса

Проведено комплексное изучение природных лечебных ресурсов (минеральных вод, пелоидов, рапы, а также климатических условий) исследуемых рекреационных территорий. Разработаны критерии оценивания природных территорий курортов для определения их будущего статуса. Приведен опыт применения их на примере трех курортов Украины. Каждый из критериев оценен за разработанной бальной шкалой. За суммой баллов определена градация на претендованный статус территорий курортов государственного или местного значения. Эта методика способствует рациональному использованию природных территорий курортов и управлению ими.

Ключевые слова: природные территории курортов; критерии оценки; статус курортов; природные лечебные ресурсы.

\section{S. Leonova}

COMPREHENSIVE DETERMINATION

EVALUATION CRITERIA OF UKRAINIAN RESORTS NATURAL TERRITORIES FOR THEIR STATUS

Ukrainian Scientific-Research Institute of Rehabilitation and Balneology of Ukraine Ministry of Health, Odessa

A comprehensive study of natural healing resources (mineral water, peloids, brine, as well as climatic conditions) within the researched recreational areas has been performed. Criteria for resorts natural areas evaluation to determine their future status has been developed. Their application experience based on the example of three Ukrainian resorts have been given. Each criterion was evaluated based on the developed grading scale. Based on points the territories claimed status has been determined as a national or local resorts level. This technique promotes the rational use and management of the resorts natural territories.

Keywords: resorts natural territories; evaluation criteria; resort status; natural healing resources. 